\title{
ASPEK PENGUASAAN KOSAKATA BAHASA INDONESIA OLEH SISWA SEKOLAH DASAR DI KOTA MEDAN
}

Aspect of Mastery Indonesian Vocabulary by Elementary School Students in Medan City

\author{
Wati Kurniawati ${ }^{1}$ dan Deni Karsana ${ }^{2}$ \\ ${ }^{1}$ Badan Pengembangan dan Pembinaan Bahasa \\ ${ }^{2}$ Balai Bahasa Sulawesi Tengah \\ 1'watikurniawati62@yahoo.com; ${ }^{2}$ karsana_s@yahoo.co.id
}

Naskah Diterima Tanggal 21 Januari 2020-Direvisi Akhir Tanggal 26 Oktober 2020-Disetujui Tanggal 27 November 2020 doi: https://doi.org/10.26499/rnh.v9i2.2977

\begin{abstract}
Abstrak
Aspek nomina dalam penguasaan kosakata bahasa Indonesia (BI) selalu dominan yang menjadi langkah awal penelitian ini. Fokus dalam penelitian ini adalah penguasaan kosakata BI oleh siswa kelas 5 SD di Kota Medan. Ada dua subfokus dalam penelitian ini, yaitu bagaimana tingkat kualifikasi dan aspek penguasaan kosakata bahasa Indonesia oleh siswa kelas 5 SD. Penelitian ini bertujuan untuk mengidentifikasi penguasaan kosakata BI oleh siswa kelas 5 SD berdasarkan (1) tingkat kualifikasi dan (2) aspek penguasaan kosakata BI. Metode yang digunakan adalah metode studi kasus. Populasi dalam penelitian ini adalah siswa SD. Sampel dalam penelitian ini ialah siswa kelas 5 SD yang berakreditasi A dan C di Kota Medan yang menjadi responden. Temuan penelitian ini ialah penguasaan kosakata BI oleh siswa SD di Kota Medan pada skala baik, yaitu 78\%. Penguasaan kosakata BI aspek nomina yang pertama dikenal siswa tidak menunjukkan yang dominan dalam penelitian ini, tetapi aspek adjektiva.

Kata-kata kunci: penguasaan kosakata, nomina, adjektiva
\end{abstract}

\begin{abstract}
The first step in this research is the always dominant the noun aspect in mastering Indonesian vocabulary. The focus in this study is how the control of Indonesian vocabulary in grade 5 SD students in Medan City. There are two sub-focusses in this study: (1) what is the level of qualification and (2) aspects of Indonesian vocabulary mastery by grade 5 elementary school students. This study aims to identify control of Indonesian vocabulary by grade 5 elementary school students based on the level of qualification and aspects of Indonesian vocabulary mastery. The method used is the case study method. The population in this study were elementary school students. The sample in this study were students of grade 5 elementary school accredited $A$ and $C$ in Medan City who were respondents. The findings of this study were the mastery of Indonesian vocabulary by elementary students in Medan City on a good scale, namely $78 \%$. The mastery of Indonesian vocabulary in the noun aspect that was first recognized by the students did not show the dominant aspect in this study, but the adjective aspect.
\end{abstract}

Keywords: vocabulary mastery, nouns, adjectives

How to Cite: Kurniawati, Wati dan Deni Karsana. (2020). Aspek Penguasaan Kosakata Bahasa Indonesia oleh Siswa Sekolah Dasar di Kota Medan. Ranah: Jurnal Kajian Bahasa. 9(2). 386-399. doi: https://doi.org/10.26499/rnh.v9i2.2977 


\section{PENDAHULUAN}

Bahan ajar bahasa Indonesia (BI) yang diberikan kepada siswa sesuai dengan ilmu pengajaran dan tingkat pendidikan siswa. Salah satu bahan ajar bahasa Indonesia adalah kosakata. Penambahan kosakata seseorang baik dari proses pembelajaran bahasa maupun pengembangan kemampuan berbahasa seseorang sangatlah penting (Alexander, 2013). Kosakata itu penting karena (1) pemahaman seseorang bertambah ketika mengetahui arti sebuah kata, (2) kata-kata adalah alat komunikasi. Menguasai kosakata dapat meningkatkan keterampilan berbahasa baik itu menyimak, berbicara, membaca, maupun menulis, dan (3) Ketika pemelajar meningkatkan kosakata mereka, kemampuan akademik dan kepercayaan diri serta kompetensinya meningkat juga (Alexander, 2013).

Kosakata merupakan salah satu materi pembelajaran bahasa Indonesia di sekolah yang menempati peran sangat penting sebagai dasar siswa untuk menguasai materi mata pelajaran bahasa Indonesia dan penguasaan mata pelajaran lainnya (Kasno, 2004 dalam Pramesti, 2015). Penguasaan kosakata memengaruhi cara berpikir dan kreativitas siswa dalam proses pembelajaran bahasa sehingga penguasaan kosakata dapat menentukan kualitas seorang siswa dalam berbahasa (Kasno, 2004 dalam Pramesti, 2015). Kualitas dan kuantitas kosakata yang dimiliki dapat membantu siswa dalam menyerap berbagai informasi yang disampaikan para pengajar atau dari berbagai sumber belajar lainnya. Penguasaan kosakata yang baik sangat memengaruhi kemampuan siswa dalam berkomunikasi, baik lisan maupun tulisan. Perbendaharaan kata yang cukup memudahkan siswa mengungkapkan segala pendapat, gagasan, pikiran, dan perasaan kepada orang lain yang tampak dalam empat kompetensi berbahasa, yakni membaca, menyimak, berbicara, dan menulis.

Penguasaan kosakata BI oleh siswa sekolah dasar (SD) beragam. Nilai Ujian Nasional (UN) atau Ujian Sekolah Berstandar Nasional (USBN) BI lebih rendah dibandingkan dengan nilai USBN Matematika. Selanjutnya, nilai USBN mengalami penurunan secara nasional (Putra, 2018). Menurut Nurgiyantoro (2013) dalam Anjarwati (2016), penguasaan kosakata dapat dibedakan ke dalam penguasaan yang bersifat reseptif dan produktif, yaitu kemampuan untuk memahami dan mempergunakan kosakata. Pada saat kegiatan membaca dan menyimak diperlukan kemampuan pemahaman, sedangkan pada kegiatan menulis dan berbicara diperlukan kemampuan penggunaan kosakata.

Sementara itu, sekolah dasar di Bogor diberikan mata pelajaran pendidikan dua bahasa, yaitu bahasa Indonesia dan bahasa Sunda. Menurut Defina et al. (2014), kendala yang dihadapi guru dalam proses pembelajaran yang lebih banyak menggunakan bahasa Indonesia daripada 
bahasa Sunda ialah keterampilan berbahasa Sunda masih kurang dan tidak mendapatkan perhatian dari pemerintah dalam upaya peningkatan kemampuan. Karena itu diharapkan ada perhatian pemerintah terhadap pembelajaran bahasa Sunda. Berbeda dengan penelitian Defina et al., (2014), A.D. Firman et al. (2019) menyatakan bahwa hasil penelitian penguasaan kosakata memiliki hubungan yang positif dan signifikan dengan kemampuan memahami unsur instrinsik cerpen pada siswa SMP kelas 8 di Kota Kendari. Ramadan dan Mulyati, (2020) menyatakan bahwa tiga kata dimaknai sesuai dengan Kamus Besar Bahasa Indonesia/KBBI (Badan Pengembangan dan Pembinaan Bahasa, 2013) dan tujuh kata dimaknai salah kaprah. Hal ini karena melihat di media massa, mendengar dari masyarakat, menjadi kebiasaan seharihari, dan melihat makna dalam kamus. Upaya memperbaiki pemaknaan itu dengan cara mewajibkan media massa untuk menggunakan makna yang sesuai dengan KBBI (Badan Pengembangan dan Pembinaan Bahasa, 2013), meningkatkan kualitas bahasa Indonesia para pendidik, menumbuhkan sikap positif terhadap bahasa Indonesia, dan menetapkan aturan yang mengikat bagi pengguna bahasa Indonesia.

Pramesti (2015) melakukan penelitian tentang pelaksanaan tindakan kelas atau action research untuk meningkatkan kosakata bahasa Indonesia dalam keterampilan membaca siswa melalui teka-teki silang. Hasil temuan adalah (1) teka-teki silang dapat diterapkan dalam pembelajaran kosakata bahasa Indonesia yang diaplikasikan dalam empat keterampilan berbahasa, yakni menyimak, berbicara, membaca, dan menulis. Peningkatan penguasaan kosakata ini terutama pada lima kosakata dasar, yakni kosakata kerja, kosakata benda, kosakata sifat, kosakata keterangan, dan kosakata perangkai atau kosakata pengganti kata orang; (2) Peningkatan ini dapat dilihat dari peningkatan nilai siswa dari tes ke tes, yakni nilai rata-rata pretes (46), nilai rata-rata tes akhir siklus satu (60), dan nilai rata-rata tes akhir siklus kedua (80).

Tarigan (2015) menjelaskan bahwa kualitas keterampilan berbahasa seseorang bergantung pada kuantitas dan kualitas kosakata yang dimilikinya. Semakin kaya kosakata yang dimiliki, semakin besar pula kemungkinan kita terampil berbahasa. Hal ini berarti bahwa penguasaan kosakata seseorang menentukan kualitas berbahasa orang tersebut. Tanpa memiliki penguasaan kosakata yang memadai maka sangat sulit bagi orang tersebut untuk mengadakan interaksi yang baik.

Berdasarkan laporan studi Programme for International Student Assessment (Litbang Kemdikbud, 2012) bahwa pada 2004 literasi membaca siswa Indonesia berada di posisi ke-39 dari 40 negara dan pada 2006 prestasi literasi membaca siswa berada pada peringkat ke-48 dari 
56 negara. Selanjutnya hasil studi Progres in International Reading Literacy Study (PIRLS) menyatakan bahwa Indonesia berada pada peringkat 41 dari 45 negara dengan skor prestasi literasi membaca siswa kelas IV Indonesia adalah 405 di bawah rata-rata internasional (500). Data tersebut menunjukkan bahwa minat baca dan tingkat kemampuan membaca siswa di Indonesia tergolong rendah.

Rahmawati et al. (2011) menjelaskan hasil temuannya, yaitu kuantitas ragam kosakata bahasa Indonesia pada anak usia prasekolah berbeda antara satu dengan yang lain. Hal ini dipengaruhi oleh beberapa faktor, yakni usia, jenis kelamin, dan kondisi lingkungan keluarga. Di samping itu, perbedaan masukan (input) yang diterima masing-masing anak juga turut berpengaruh dalam kuantitas ragam kosakata yang dikuasai anak. Sementara itu, dari segi penguasaan terhadap kelas kata bahasa Indonesia, kosakata anak sudah mencakup hampir seluruh kelas kata yang ada, yakni nomina, verba, adjektiva, adverbia, pronomina, numeralia, preposisi, konjungsi, dan interjeksi. Dari hasil penelitian ini, kelas kata nomina menempati posisi terbanyak yang dikuasai anak. Hal itu berbanding terbalik dengan kelas kata artikula yang tidak ditemukan sama sekali dalam tuturan anak-anak yang diteliti.

Penelitian penguasaan kosakata bahasa Indonesia oleh siswa telah banyak dilakukan peneliti bahasa. Misalnya, penelitian (Pramesti, 2015) dengan metode action research untuk meningkatkan kosakata bahasa Indonesia dalam keterampilan membaca siswa melalui teka-teki silang. Hasil temuan adalah peningkatan penguasaan kosakata pada lima kosakata dasar, yakni kosakata kerja, benda, sifat, keterangan, dan perangkai atau pengganti kata orang. Rahmawati et al. (2011) menjelaskan hasil temuannya, yaitu kuantitas ragam kosakata bahasa Indonesia pada anak usia prasekolah dipengaruhi faktor usia, jenis kelamin, dan kondisi lingkungan keluarga. Penguasaan kosakata anak sudah mencakup hampir seluruh kelas kata yang ada, yaitu nomina, verba, adjektiva, adverbia, pronomina, numeralia, preposisi, konjungsi, dan interjeksi. Kelas kata nomina menempati posisi terbanyak yang dikuasai anak. Hal itu berbanding terbalik dengan kelas kata artikula yang tidak ditemukan sama sekali dalam tuturan anak-anak yang diteliti. Kebaruan penelitian (state of the art) ini tidak hanya mengidentifikasi kelas kata, tetapi makna, perhubungan makna (sinonim dan antonim), dan bentuk kata (kata dasar dan kata berimbuhan). Penguasaan kosakata aspek nomina yang pertama dikenal anak tidak menunjukkan yang dominan dalam penelitian ini, tetapi aspek adjektiva. Jenis penguasaan kosakata ini bersifat aktif reseptif. 
Dari beberapa tulisan tersebut, penulis belum melihat secara khusus mengenai penguasaan kosakata bahasa Indonesia oleh siswa kelas 5 SD, khususnya di kota Medan. Untuk itu, penelitian ini dilakukan dengan fokus penguasaan kosakata BI oleh siswa kelas 5 SD dengan subfokus, yaitu bagaimana tingkat kualifikasi dan aspek penguasaan kosakata bahasa Indonesia oleh siswa kelas 5 SD. Penelitian ini bertujuan untuk mengidentifikasi peguasaan kosakata BI oleh siswa kelas 5 SD berdasarkan (1) tingkat kualifikasi dan (2) aspek penguasaan kosakata BI oleh siswa kelas 5 SD.

\section{LANDASAN TEORI}

Penguasaan kosakata adalah kemampuan siswa untuk mengenal, memahami, dan menggunakan kata-kata yang terdapat dalam suatu bahasa dengan tepat. Penguasaan kosakata bukan keterampilan yang sederhana. Siswa harus melalui tahapan dalam proses penguasaan kosakata agar dapat berkembang dengan baik dan benar. Tahapan tersebut terdiri atas masa kanak-kanak, remaja, dan dewasa (Keraf, 2009).

Hurlock (2009) menyatakan bahwa kosakata yang harus dikuasai oleh anak-anak usia 6-13 tahun atau siswa SD ada dua jenis, yakni kosakata umum dan koakata khusus. Kosakata umum, mencakup kata-kata umum yang digunakan manusia untuk berkomunikasi yang termasuk kelas kata verba, nomina, adjektiva, adverbia, konjungsi, dan pronomina. Berbeda dengan kosakata umum, kosakata khusus adalah kata-kata khusus, seperti kosakata waktu, warna, uang, rahasia, populer, dan makian.

Susanto (2013) mengatakan bahwa perkembangan bahasa anak pada usia sekolah dasar merupakan masa berkembang pesatnya kemampuan mengenal dan menguasai perbendaharaan kata (vocabulary). Dalam proses pertumbuhan perbendaharaan kata selama masa sekolah, anak-anak juga semakin banyak menggunakan kata yang tepat untuk menjelaskan suatu tindakan. Ketika memasuki usia sekolah dasar, anak-anak akan terkondisikan untuk mempelajari bahasa tulis (Susanto, 2013). Pada masa ini anak dituntut untuk berpikir lebih dalam sehingga kemampuan berbahasa anak mengalami perkembangan. Perkembangan bahasa pada fase kanak-kanak tengah akhir tampak pada perubahan perbendaharaan kata dan tata bahasa. Pada tahap ini anak belajar memilih kata yang tepat untuk penggunaan tertentu dan mempelajari bahasa tulis sehingga anak mudah menulis suatu karangan.

Standar penguasaan kosakata untuk tingkat SD beragam. Jumlah kosakata SD \pm 9.000

kata dalam "Pengajaran Bahasa dan Pendekatan Pragmatik" (Nababan, 1988). Dalam kurikulum untuk sekolah dasar dan menengah 1994 disebutkan bahwa penguasaan kosakata 
untuk lulusan SD adalah 3.500 kata (Depdikbud, 1994 dalam Gafari, 2001). Pada kurikulum berbasis kompetensi dinyatakan bahwa penguasaan kosakata untuk lulusan SD adalah 9.000 kata (Depdiknas, 2000 dalam Gafari, 2001). Berdasarkan kurikulum 2004, dinyatakan bahwa standar penguasaan kosakata untuk setiap tingkat berbeda, yaitu (1) standar penguasaan 500-1500 kosakata (vocabulary) termasuk kategori pembaca tingkat pemula dengan jenjang pendidikan sekolah dasar (SD) sampai dengan sekolah menengah pertama /SMP (Departemen Pendidikan Nasional, 2003).

Dalam menentukan tingkat penguasaan kosakata BI siswa SD, dilakukan dengan cara penentuan patokan dengan penghitungan persentase skala 5 yang dikonversi dari skala 4 (Nurgiyantoro, 2013). Penentuan kriteria dengan penghitungan persentase untuk skala 4 ialah sebagai berikut.

Tabel 1.

Tingkat Penguasaan Kosakata Bahasa Indonesia Skala 4

\begin{tabular}{cccc}
\hline \multirow{2}{*}{$\begin{array}{c}\text { Interval Persentase Tingkat } \\
\text { Penguasaan }\end{array}$} & \multicolumn{2}{c}{ Nilai Ubahan Skala Empat } & \multirow{2}{*}{ Keterangan } \\
\cline { 2 - 3 } & $1-4$ & $\mathrm{D}-\mathrm{A}$ & \\
\hline $86-100$ & 4 & $\mathrm{~A}$ & Baik sekali \\
\hline $76-85$ & 3 & $\mathrm{~B}$ & Baik \\
\hline $56-74$ & 2 & $\mathrm{C}$ & Cukup \\
\hline $10-55$ & 1 & $\mathrm{D}$ & Kurang \\
\hline & & \multicolumn{2}{c}{ Sumber: Nurgiyantoro(2013) }
\end{tabular}

Contoh penghitungan, siswa memperoleh skor 62 dari 75 butir soal yang tersedia atau kemungkinan tertinggi. Hal itu menunjukkan bahwa siswa mampu menjawab soal sekitar $83 \%$ (62 dibagi 75 dikali 100\%). Jika ditransformasikan ke skala 4, diperoleh nilai 3 atau baik.

Berikut tingkat penguasaan kosakata berdasarkan skala 5.

Tabel 2.

Tingkat Penguasaan Kosakata Bahasa Indonesia Skala 5

\begin{tabular}{cccc}
\hline Interval Persentase & \multicolumn{2}{c}{ Nilai Ubahan Skala Lima } & \multirow{2}{*}{ Keterangan (kualifikasi) } \\
\cline { 2 - 3 } Tingkat Penguasaan & $1-5$ & E-A & \\
\hline $80-100$ & 5 & A & Baik sekali \\
\hline $70-79$ & 4 & B & Baik \\
\hline $60-69$ & 3 & C & Cukup \\
\hline $50-59$ & 2 & D & Kurang \\
\hline $0-49$ & 1 & E & Sangat kurang \\
\hline & & Sumber: dikonversi dari Nurgiyantoro(2013)
\end{tabular}

\section{METODE PENELITIAN}

Metode yang digunakan adalah metode studi kasus. Hal ini dikarenakan penelitian ini menjelaskan dan memahami objek yang diteliti secara khusus sebagai studi kasus, yaitu penguasaan kosakata bahasa Indonesia oleh siswa SD kelas 5 di kota Medan. Sebagaimana Yin (2013) menyatakan bahwa tujuan penggunaan penelitian studi kasus adalah tidak sekadar untuk 
menjelaskan seperti apa objek yang diteliti, tetapi untuk menjelaskan bagaimana keberadaan dan mengapa kasus tersebut terjadi. Selanjutnya, studi kasus adalah suatu penelitian yang dilakukan secara menyeluruh dan intensif serta mendetail terhadap suatu kasus tertentu (Amir et al., 2009). Teknik pengumpulan data melalui observasi, wawancara pada siswa dan guru SD di Medan, catat-rekam, dan instrumen penelitian, yaitu kuesioner. Prosedur pengumpulan data dilakukan dengan kuesioner terhadap dua kelas siswa yang berbeda sekolah dasar. Siswa mengisi daftar tanyaan kosakata berupa pilihan ganda yang menunjukkan penguasaan kosakata setiap siswa. Kuesioner berisi daftar tanyaan berupa pilihan ganda yang berjumlah 120 soal yang digunakan untuk mengukur penguasaan kosakata siswa. Kuesioner kosakata yang disusun berdasarkan tes kosakata dan buku paket bahasa Indonesia untuk kelas 5 SD yang diunduh dari Bse.kemdikbud.go.id (buku teks yang diunduh dipilih berdasarkan kurikulum 2013). Buku teks merupakan bahan ajar atau media instruksional yang dominan untuk kegiatan belajar-mengajar dan berguna untuk menyampaikan materi kurikulum (Supriadi, 1999). Tema dalam buku pegangan guru dan siswa berdasarkan kurikulum 2013 meliputi benda-benda di lingkungan sekitar, peristiwa dalam kehidupan, kerukunan dalam bermasyarakat, sehat itu penting, dan bangga sebagai bangsa Indonesia. Kisi-kisi tes penguasaan kosakata terdiri atas (1) jenis penguasaan kosakata, yaitu aktif reseptif; dan (2) indikator atau aspek, yaitu kelas kata (nomina, verba, adjektiva, dan kata tugas), makna, perhubungan makna (sinonim dan antonim), dan bentuk kata (kata dasar dan kata berimbuhan).

Populasi dalam penelitian ini adalah siswa SD yang berakreditasi A dan C di Kota Medan. Sampel dalam penelitian ini ialah siswa kelas 5 SD yang menjadi responden berjumlah 70 siswa. Hal ini sesuai dengan ukuran sampel yang layak dalam penelitian yakni antara 30 dan 500 jika sampel dibagi dalam kategori (misalnya: laki-laki dan perempuan), jumlah anggota sampel setiap kategori minimal 30 (Sugiyono, 2017). Penetapan responden sebagai sampel dengan menggunakan teknik purposive sampling (teknik pengambilan sampel secara sengaja dengan pertimbangan tertentu sesuai dengan tujuan penelitian ini). Sampel penelitian diambil tidak secara acak, tetapi ditentukan peneliti sesuai dengan karakteristik responden yang dijadikan variabel dalam penelitian ini. Responden terdiri atas siswa laki-laki dan perempuan serta berusia, 10 - 13 tahun. Data terdiri atas data primer dan sekunder. Data primer merupakan data utama yang diperoleh dari jawaban responden. Sementara itu, data sekunder diperoleh dari studi pustaka.

Dalam pengolahan data ditabulasikan data primer dari jawaban responden. Data hasil tabulasi dalam program Excel diolah untuk mengetahui tingkat penguasaan kosakata siswa. 
Data yang telah diolah tersebut kemudian dianalisis. Data kualitatif berupa rekaman (transkripsi) dan catatan lapangan diinterpretasikan sesuai dengan keperluan analisis yang dilakukan.

\section{PEMBAHASAN}

Fokus dalam penelitian ini adalah penguasaan kosa kata oleh siswa kelas 5 SD di Kota Medan yang disubfokuskan pada dua subfokus, yaitu bagaimana tingkat kualifikasi dan aspek penguasaan kosakata bahasa Indonesia. Berikut ini adalah uraiannya masing-masing.

\section{Tingkat Kualifikasi}

Sampel dalam penelitian ini adalah 70 siswa kelas 5 SD yang menjadi responden. Data penguasaan kosakata diperoleh berdasarkan tes penguasaan kosakata untuk siswa sekolah dasar yang terdiri atas 120 item soal pilihan ganda. Soal tersebut dengan skor benar 1 dan skor salah 0. Berdasarkan analisis data, skor tertinggi ialah 114 dari 120 butir soal (114 dibagi 120 dikali 100\% menjadi 95\%). Dengan demikian, siswa mampu menjawab soal sekitar 95\% jika ditransformasikan ke skala 5, diperoleh nilai 5 atau baik sekali. Sementara itu, skor terendah ialah 59, sehingga siswa mampu mengerjakan 49\%. Jika ditransformasikan ke skala 5, diperoleh nilai 1 atau sangat kurang. Skor rata-rata ialah 93, sehingga siswa mampu mengerjakan 77,50\%jika ditransformasikan ke skala 5 maka diperoleh nilai 4 atau baik.

Jumlah kelas interval ditentukan dengan rumus Sturges (Sugiyono, 2015), yaitu jumlah kelas $=1+3.3 \log \mathrm{n}, \mathrm{n}$ merupakan jumlah responden. Berdasarkan data $\mathrm{n}=70$, jumlah kelas 1 +3.3 $\log 70=7,09$ dibulatkan menjadi 7 kelas interval. Rentang data dihitung dengan rumus nilai maksimal - nilai minimal selanjutnya ditambah 1 . Rentang data $95-49=46+1=47$. Panjang kelas (rentang) $/ \mathrm{K}=(47) / 7=6,71$ (7)

Tabel 3.

Distribusi Frekuensi Penguasaan Kosakata

\begin{tabular}{ccc}
\hline \multicolumn{3}{c}{ Distribusi Frekuensi Penguasaan Kosakata } \\
\hline 1. & Kelas Interval & Frekuensi \\
\hline 2. & $49-56$ & 6 \\
\hline 3. & $56-63$ & 4 \\
\hline 4. & $63-69$ & 11 \\
\hline 5. & $69-76$ & 7 \\
\hline 6. & $76-83$ & 8 \\
\hline 7. & $83-89$ & 25 \\
\hline \multicolumn{4}{c}{ Sumber: Data Primer Diolah 2017 }
\end{tabular}


Berdasarkan distribusi frekuensi penguasaan kosakata pada Tabel 3 dapat digambarkan dalam diagram batang sebagai berikut

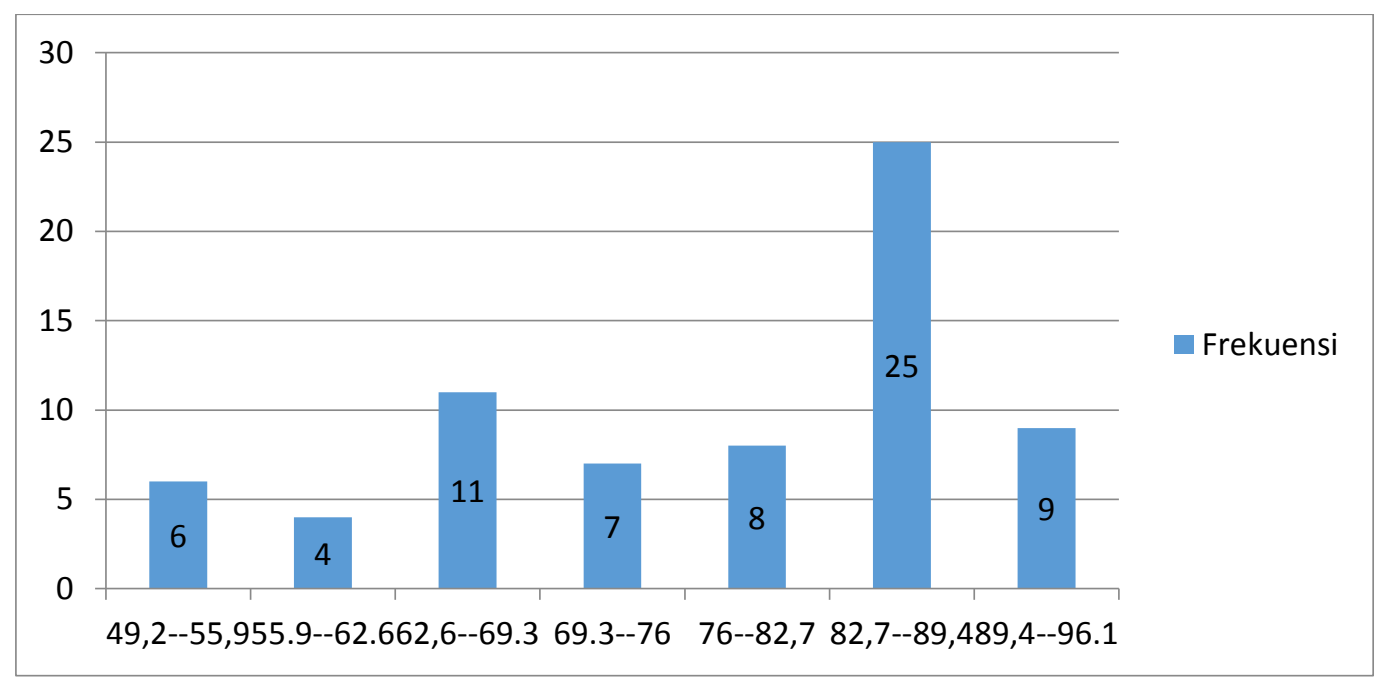

Gambar 1. Diagram batang Distribusi Frekuensi Penguasaan Kosakata

Berdasarkan tabel dan diagram batang penguasaan kosakata, diidentifikasi siswa mampu menjawab pertanyaan, yaitu 49,2-55,9\% ada 6 siswa, 55,9-62,6\% ada 4 siswa, 62,6-69,3 $\%$ ada 11 siswa, 69,3-76\% ada 7 siswa, 76-82,7\% ada 8 siswa, 82,7-89,4\% ada 25 siswa, dan $89,4-96,1 \%$ ada 9 siswa. Persentase rata-rata siswa mampu menjawab pertanyaan ialah 78\%. Jika ditransformasikan ke skala lima, diperoleh nilai 2 atau kurang ada 7 siswa, nilai 3 atau cukup ada 15 siswa, nilai 4 atau baik ada 8 siswa, nilai 5 atau baik sekali ada 40 siswa. Rata-rata diperoleh nilai 4 atau baik. Dengan demikian, penguasaan kosakata siswa kelas 5 SD ini termasuk kategori baik.

\section{Aspek Penguasaan Kosakata}

Penguasaan kosakata yang diukur bersifat aktif-reseptif. Indikator dalam penelitian ini terdiri atas (1) memilih kosakata berdasarkan kelas kata, yaitu nomina (kosakata roda, tumit, kursi, meja, telunjuk, rok, ikan tuna, bayam, racun, istana, pensil, kereta api, bus, handuk, garasi, mawar, korban, manisan, pahlawan, oksigen, kritikan, dan penjambret), verba (kosakata menyikat, banjir, mencekam, penebangan, berekreasi, bersolek, terjepit, mengantuk, dan terpincang-pincang), adjektiva (kosakata sangat lezat, sakit, sangat luas, boros, lezat, sopan, ramah, paling, dan basi), dan kata tugas (kosakata kapan, pada, apa, karena, dalam, sudah, di, sebelum(nya), dan siapa), (2) memilih kata yang sesuai dengan uraian makna (kosakata tidak mempunyai uang, orang yang bekerja dalam kemiliteran, bergerak cepat, musim kemarau, antara dua orang atau lebih, anak satu-satunya, narasumber, kusut, rajin, 
dokter, tidak bekerja, informasi, bagian penghabisan, pertanyaan, mengatakan yang benar, utang, angkutan, dapat, sesuatu yang keras, sedih, menyelamatkan diri, memasak, datang, peristiwa, mengangkat anak orang lain sebagai anak sendiri, orang yang pasti bersalah, tempat jual beli ikan, Candra terjatuh dari sepeda, kekeringan, dan pelucutan senjata), (3) memilih perhubungan makna, yaitu sinonim (kosakata tabah, tidak puas, angkuh, menjenguk, piknik, pengembara, bermanfaat, menaati, pendapat, karnivora, dan sepakat) dan antonim (kosakata ramai, sendiri, berjumpa, sesudah, dan menyenangkan), dan (4) memilih kata berdasarkan bentuk kata, yaitu kata dasar (sarapan dan jajan) serta kata berimbuhan (kosakata terjatuh, lemparkan, siramlah, bawakan, kunjungilah, mengilapkan, bekerja, pengalaman, jauhilah, terbaik, merawat, terpilih, berlangsung, terlambat, dibakar, dan menolong). Berdasarkan keempat indikator itu dirinci menjadi 9 aspek, yaitu nomina, verba, adjektiva, kata tugas, makna, sinonim, antonim, kata dasar, dan kata berimbuhan. Nilai setiap indikator ialah sebagai berikut.

Penguasaan kosakata siswa berdasarkan aspek nomina jika ditransformasikan ke skala lima, diketahui sebanyak 14 butir soal dijawab dengan betul oleh siswa digolongkan dengan kategori baik sekali ( $80-100 \%)$. Ada 4 butir soal dijawab dengan betul oleh siswa digolongkan dengan kategori baik (70-77\%). Adapun 1 butir soal dijawab dengan betul oleh siswa digolongkan dengan kategori cukup (67\%). Ada 2 butir soal dijawab dengan betul oleh siswa digolongkan dengan kategori sangat kurang (24\%). Rata-rata penguasaan kosakata siswa SD berdasarkan aspek nomina diperoleh nilai 5 atau dikategorikan baik sekali (81\%).

Penguasaan kosakata siswa berdasarkan aspek verba jika ditransformasikan ke skala lima, diketahui sebanyak 5 butir soal dijawab dengan betul oleh siswa digolongkan dengan kategori baik sekali (80-99\%). Ada 3 butir soal dijawab dengan betul oleh siswa digolongkan dengan kategori baik $(70-77 \%)$. Adapun 1 butir soal dijawab dengan betul oleh siswa digolongkan dengan kategori cukup (67\%). Rata-rata penguasaan kosakata verba siswa SD dikategorikan baik sekali $(80 \%)$.

Penguasaan kosakata siswa berdasarkan aspek adjektiva jika ditransformasikan ke skala lima, diketahui sebanyak 9 butir soal dijawab dengan betul oleh siswa digolongkan dengan kategori baik sekali (87-100\%). Ada 1 butir soal dijawab dengan betul oleh siswa digolongkan dengan kategori baik (79\%). Penguasaan kosakata siswa berdasarkan aspek kata tugas. Ratarata penguasaan kosakata adjektiva siswa SD dikategorikan baik sekali (93\%).

Penguasaan kosakata siswa berdasarkan aspek kata tugas jika ditransformasikan ke skala lima, diketahui sebanyak 12 butir soal dijawab dengan betul oleh siswa digolongkan dengan 
kategori baik sekali (87-100\%). Ada 3 butir soal dijawab dengan betul oleh siswa digolongkan dengan kategori baik (71-74\%). Adapun 1 butir soal dijawab dengan betul oleh siswa digolongkan dengan kategori kurang (50\%). Ada 2 butir soal dijawab dengan betul oleh siswa digolongkan dengan kategori sangat kurang (31-36\%). Rata-rata penguasaan kosakata siswa SD berdasarkan aspek kata tugas dikategorikan baik (79\%).

Penguasaan kosakata siswa berdasarkan aspek makna jika ditransformasikan ke skala lima diketahui sebanyak 17 butir soal dijawab dengan betul oleh siswa digolongkan dengan kategori baik sekali. Ada 5 butir soal dijawab dengan betul oleh siswa digolongkan dengan kategori baik. Adapun 1 butir soal dijawab dengan betul oleh siswa digolongkan dengan kategori cukup. Ada 4 butir soal dijawab dengan betul oleh siswa digolongkan dengan kategori kurang. Ada 3 butir soal dijawab dengan betul oleh siswa digolongkan dengan kategori sangat kurang. Rata-rata penguasaan kosakata siswa SD berdasarkan aspek makna dikategorikan baik $(77 \%)$.

Penguasaan kosakata siswa berdasarkan aspek sinonim jika ditransformasikan ke skala lima diketahui sebanyak 6 butir soal dijawab dengan betul oleh siswa digolongkan dengan kategori baik sekali. Ada 1 butir soal dijawab dengan betul oleh siswa digolongkan dengan kategori baik. Ada 1 butir soal dijawab dengan betul oleh siswa digolongkan dengan kategori cukup. Ada 3 butir soal dijawab dengan betul oleh siswa digolongkan dengan kategori sangat kurang. Rata-rata penguasaan kosakata sinonim siswa SD dikategorikan baik (70\%).

Penguasaan kosakata siswa berdasarkan aspek antonim jika ditransformasikan ke skala lima diketahui sebanyak 1 butir soal dijawab dengan betul oleh siswa digolongkan dengan kategori cukup (66\%). Ada 2 butir soal dijawab dengan betul oleh siswa digolongkan dengan kategori kurang (53-59\%). Adapun 2 butir soal dijawab dengan betul oleh siswa digolongkan dengan kategori sangat kurang (46-49\%). Rata-rata penguasaan kosakata antonim siswa SD dikategorikan kurang (54\%).

Penguasaan kosakata siswa kelas 5 SD berdasarkan aspek kata dasar jika ditransformasikan ke skala lima diketahui sebanyak 2 butir soal dijawab dengan betul oleh siswa digolongkan dengan kategori baik sekali.Rata-rata penguasaan kosakata kata dasar siswa SD dikategorikan baik sekali $(95 \%)$.

Penguasaan kosakata siswa berdasarkan aspek kata berimbuhan jika ditransformasikan ke skala 5 diketahui sebanyak 2 butir soal dijawab dengan betul oleh siswa digolongkan dengan kategori baik sekali. Rata-rata penguasaan kosakata siswa SD pada aspek berimbuhan dikategorikan baik (74\%). 
Dengan demikian, rata-rata hasil tes penguasaan kosakata siswa kelas 5 SD dikategorikan baik sekali pada aspek nomina (81\%), verba (80\%), adjektiva (93\%), dan kata dasar (95\%). Selanjutnya, dikategorikan baik pada aspek kata tugas (79\%), makna (77\%), sinonim (70\%), dan kata berimbuhan (74\%). Aspek antonim (54\%) dikategorikan kurang.

Berikut tabel rata-rata hasil tes penguasaan kosakata siswa kelas 5 SD berdasarkan 9 aspek.

Tabel 4.

Rata-rata Hasil Tes Penguasaan Kosakata Siswa Berdasarkan 9 Aspek

\begin{tabular}{cccc}
\hline Aspek & Frekuensi & Persentase $(\%)$ & Keterangan \\
\hline Nomina & 57 & 81 & Baik sekali \\
\hline Verba & 56 & 80 & Baik sekali \\
\hline Adjektiva & 65 & 93 & Baik sekali \\
\hline Kata Tugas & 55 & 79 & Baik \\
\hline Makna & 54 & 77 & Baik \\
\hline Sinonim & 49 & 70 & Baik \\
\hline Antonim & 38 & 54 & Burang \\
\hline Kata Dasar & 66,5 & 95 & Baik \\
\hline Kata Berimbuhan & 52 & 74 &
\end{tabular}

Distribusi frekuensi data pada Tabel 4 dapat digambarkan dalam bentuk pie chart berikut.

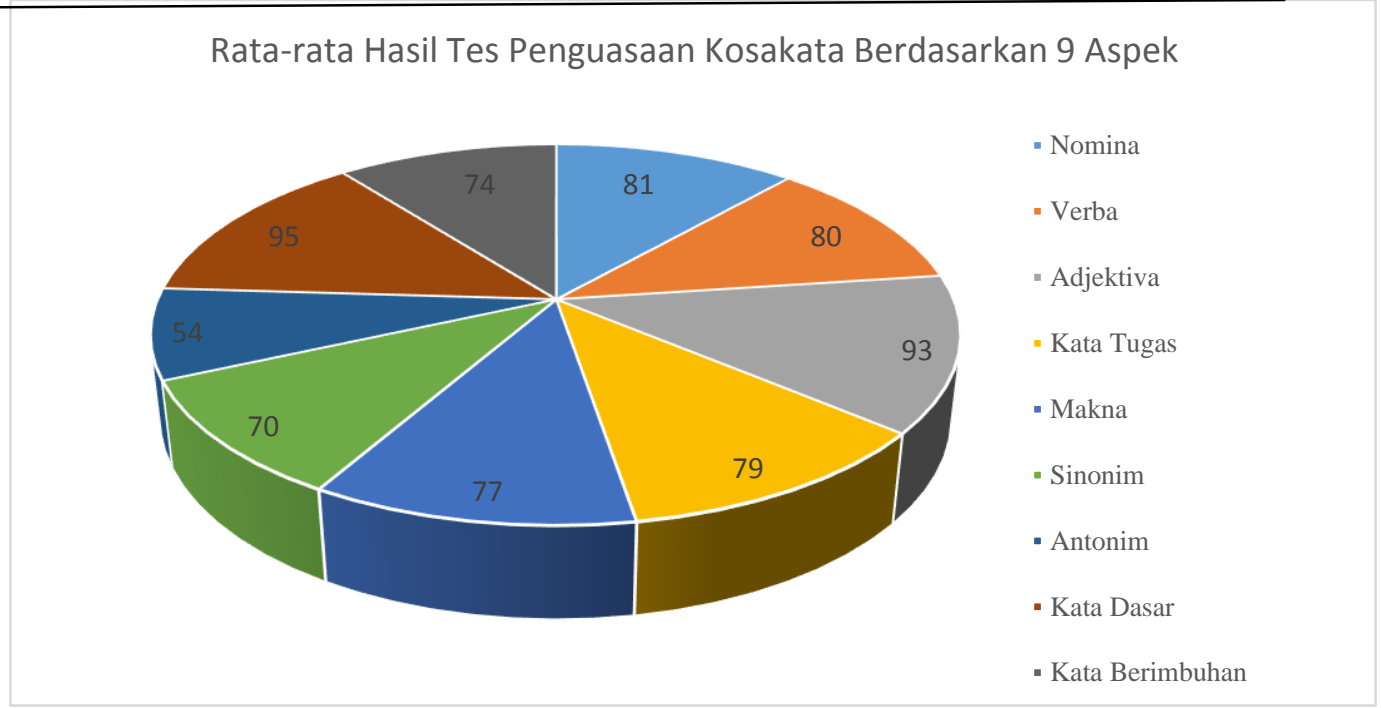

Gambar 2. Pie Chart Rata-Rata Hasil Tes Penguasaan Kosakata Siswa Kelas 5 SD Berdasarkan 9 Aspek

Berdasarkan Tabel 4 dan pie chart penguasaan kosakata itu, dapat diketahui bahwa siswa yang memiliki tingkat penguasaan kosakata dengan kategori baik sekali sebanyak 4 aspek, yaitu nomina (81\%), verba (80\%), adjektiva (93\%), dan kata dasar (95\%). Siswa yang memiliki tingkat penguasaan kosakata dengan kategori baik sebanyak 4 aspek, yaitu aspek kata tugas (79\%), makna (77\%), sinonim (70\%), dan kata berimbuhan (74\%). Siswa yang memiliki tingkat penguasaan kosakata dengan kategori kurang hanya 1 aspek, yaitu antonim (54\%). Berdasarkan 
9 aspek yang ditanyakan kepada siswa kelas 5 SD ini, penguasaan kosakata pada aspek antonim termasuk kategori kurang. Dengan demikian, dari penelitian ini penguasaan siswa SD kelas 5 di Kota Medan terhadap kosakata bahasa Indonesia secara keseluruhan, yakni aspek penguasaan kosakata adalah baik (delapan aspek berbanding satu aspek).

\section{PENUTUP}

Temuan penelitian ini mengidentifikasi dua subfokus penguasaan kosakata siswa kelas 5 SD di Kota Medan, yaitu kualifikasi dan aspek. Skor rata-rata penguasaan kosakata siswa kelas 5 SD yang ditransformasikan ke skala 5 diperoleh nilai baik. Dari hasil penelitian diidentifikasi siswa mampu menjawab pertanyaan, yaitu 49,2-55,9\% ada 6 siswa, 55,9-62,6\% ada 4 siswa, $62,6-69,3 \%$ ada 11 siswa, 69,3-76\% ada 7 siswa, 76-82,7\% ada 8 siswa, $82,7-89,4 \%$ ada 25 siswa, dan $89,4-96,1 \%$ ada 9 siswa.

Adapun rata-rata penguasaan kosakata siswa kelas 5 SD berdasarkan 9 aspek yang paling dominan adalah kata dasar dengan kualifikasi baik sekali jika dibandingkan dengan 8 aspek yang lain. Berdasarkan kelas kata, aspek adjektiva (seperti kosakata sangat lezat, sakit, sangat luas, boros, lezat, sopan, ramah, paling, dan basi) lebih dominan daripada aspek nomina, verba, dan kata tugas. Aspek nomina yang pertama dikenal anak tidak menunjukkan yang dominan dalam penguasaan kosakata. Aspek makna, kata berimbuhan, dan sinonim dengan kualifikasi baik; dan antonim dengan kualifikasi kurang. Berdasarkan hasil temuan, perlu ditingkatkan materi ajar aspek antonim. Dalam proses belajar-mengajar bahan ajar aspek antonim perlu ditingkatkan, sehingga siswa dapat memahami dan menggunakan kosakata antonim dengan tepat.

\section{DAFTAR PUSTAKA}

Alexander, F. (2013). Understanding Vocabulary. Retrieved 2017 August 10 from www.teacher.scolastic.com.

Amir, A., Junaidi, J., \& Yulmardi, Y. (2009). Metodologi Penelitian Ekonomi dan Penerapannya. Bogor: IPB Press.

Anjarwati, E. (2016). Pengaruh Penguasaan Kosakata terhadap Kemampuan Membaca Pemahaman Siswa SD Gugus Dewi Kunthi Kota Semarang. Skripsi Fakultas Ilmu Pendidikan. Semarang: Universitas Negeri Semarang.

A.D., Firman., Hastuti, H. B. P., Sukmawati, \& Rahmawati. (2019). Analisis Hubungan Penguasaan Kosakata dan Kemampuan Memahami Unsur Intrinsik Cerpen Siswa SMP di Kota Kendari. Ranah: Jurnal Kajian Bahasa. https://doi.org/10.26499/rnh.v8i1.636

Badan Pengembangan dan Pembinaan Bahasa. (2013). Kamus Besar Bahasa Indonesia. Jakarta: Balai Pustaka.

Defina, D., Krishandini, K., Arianti, L., Krishnawati, H., \& Sulistyowati, H. (2014). Pembelajaran Dwibahasa di Sekolah Dasar: Pelaksanaan, Kendala, dan Harapan. Ranah: Jurnal Kajian Bahasa. https://doi.org/10.26499/rnh.v3i1.20 
Gafari, M. O. F. (2001). Kosakata Akademik pada Buku Sekolah Elektronik Tingkat SD, SMP Dan SMA. Jurnal Bahas Unimed, 27(1), 74555.

Hurlock, E. B. (2009). Psikologi Perkembangan: Suatu Pendekatan Sepanjang Rentang Kehidupan. Alih bahasa Istiwidayanti \& Soedjarwo. Jakarta: Erlangga.

Kemdikbud, B. (2012). Survei Internasional PISA (Programme for International Student Assessment). Jakarta: Litbang Kemdikbud.

Keraf, G. (2009). Diksi dan gaya bahasa. Jakarta: Gramedia Pustaka Utama.

Nababan, P. W. J. (1988). Pengajaran Bahasa dan Pendekatan Pragmatik dalam Bulir-Bulir Sastra \& Bahasa: Pembaharuan Pengajaran. Jakarta: Kanisius.

Nasional, Departemen Pendidikan. (2003). Kurikulum 2004. Jakarta: Depdiknas.

Nurgiyantoro, B. (2013). Penilaian Pembelajaran Bahasa Berbasis Kompetensi [Assessment of Bahasa Learning Based on Competence]. Yogyakarta, Indonesia: Badan Percetakan Fakultas Ekonomi Universitas Negeri Yogyakarta.

Pramesti, U. D. (2015). Peningkatan Penguasaan Kosakata Bahasa Indonesia dalam Keterampilan Membaca Melalui Teka-Teki Silang (Penelitian Tindakan di Kelas VI SDN Surakarta 2, Kecamatan Suranenggala, Kabupaten Cirebon, Jawa Barat). Puitika, 11(1), 82-93.

Putra, E. (2018). Hanya Sembilan Siswa yang Meraih Nilai 100 USBN SD. https://sukoharjonews.com/hanya-sembilan-siswa-yang meraih-nilai-100-usbn-sd/.

Rahmawati, D., Sunaryo, H. S., \& Widodo, H. S. (2011). Penguasaan Kosakata Bahasa Indonesia pada Anak Usia Prasekolah. Jurnal Penelitian Paudia, 1(1), 1-12.

Ramadan, S., \& Mulyati, Y. (2020). Makna Kata dalam Bahasa Indonesia (Salah Kaprah dan Upaya Perbaikannya). Ranah: Jurnal Kajian Bahasa. https://doi.org/10.26499/rnh.v9i1.1036

Sugiyono. (2015). Statistika untuk Penelitian [Statistic for Research]. Bandung: Alfabeta.

Sugiyono. (2017). Metode Penelitian: Kuantitatif, Kualitatif, dan R \&D. Bandung: Alfabeta.

Supriadi, D. (1999). Mengangkat Citra dan Martabat Guru. Yogyakarta: Adicita Karya Nusa.

Susanto, A. (2013). Teori Belajar dan Pembelajaran di Sekolah Dasar. Jakarta: Kencana Prenada Media Group.

Tarigan, H. G. (2015). Pengajaran Kosakata. Bandung: Angkasa. 